$$
\text { CONIF- } 930644^{2 / 22 / 93}-6^{2}
$$

\title{
THE INFLUENCE OF STRAIN RATE AND SAMPLE INHOMOGENEITY ON THE MODULI AND STRENGTH OF WELDED TUFF*
}

\author{
R.J. Martin, $\mathrm{m}^{\dagger}$, R.H. Priceł, P.J. Boyd ${ }^{\dagger}$, and J.S. Noel ${ }^{\dagger}$ \\ $\dagger_{\text {New England Research, Inc. }}$ \\ White River Junction, VT 05001 \\ SAND--92-2152C \\ DE93 009626 \\ ¥Sandia National Laboratories \\ Albuquerque, New Mexico 87185
}

\begin{abstract}
A series of constant strain rate, unconfined compression experiments was performed on saturated welded tuff specimens collected from Busted Butte near Yucca Mountain, Nevada. Twenty specimens were loaded to failure at strain rates ranging from $10^{-9} \mathrm{~s}^{-1}$ to $10^{-3} \mathrm{~s}^{-1}$, under ambient pressure and temperature conditions. The strength of the specimens showed a continuous decrease with decreasing strain rate between $10^{-9} \mathrm{~s}^{-1}$ and. $10^{-5} \mathrm{~s}^{-1}$. At the highest strain rate, $10^{-3} \mathrm{~s}^{-1}$, strengths were less than those observed at $10^{-5} \mathrm{~s}^{-1}$, likely due to hydrofracturing within the specimen at rapid loading rates.

Reduction in strength, corresponding to the decrease in strain rate, is explained in terms of stress corrosion cracking. A detailed examination of six specimens tested at a strain rate of $10^{-9} \mathrm{~s}^{-1}$, using acoustic wave velocities and CT scans, shows a correlation betweeri the nature of the microstructure of the specimens and the observed strengths and elastic moduli.
\end{abstract}

- 1 This work was performed under the auspices of the U.S. Department of Energy (DOE), Office of Civilian Radioactive Waste Management, Yucca Mountain Site Characterization Project, under Contract No. DE-AC04-76DP00789. 


\section{INTRODUCTION}

The strength of brittle rock is not a single valued function of confining pressure and temperature. Strength is, in fact, a rather ambiguous term and depends on many parameters such as the loading conditions (in particular, rate), the effective pressure, composition of the pore fluid, the distribution of cracks and heterogeneities within the rock, and the scale of the sample under consideration. It is well known that brittle rocks are strongly influenced by the moisture content in the pore space. Water facilitates stress corrosion at the tips of micro-cracks under load (Martin, 1972; Scholz, 1972; Costin, 1983; and Atkinson, 1984). The effect of stess corrosion cracking in brittle rocks is to reduce the strength with increasing partial pressure of water, increasing temperature, and decreasing loading rate. In most cases, it is difficult to document the partial pressure of water within the pore space. Complete saturation provides the most unambiguous condition.

The scale of the rock mass under consideration also greatly influences the observed strength. In a laboratory environment, as the dimensions of the specimen increase, the fracture strength decreases (Price, 1986). This is attributable to the inclusion

of larger, critically oriented flaws that control the strength of the rock under fixed environmental conditions as the sample size increases. Hueze (1980) observed similar behavior by showing that large volumes of rock tested in situ exhibit significantly lower strengths than those measured in laboratory experiments. Presently, no scaling law exists that permits us to take all the parameters into account and predict in situ behavior from laboratory measurements.

In light of the significance of environmental parameters, strain rate, and sample dimensions on the observed strength of rocks, it is important that the functional relation between each of these properties be considered when incorporated into models. This is 
important for the potential nuclear waste repository at Yucca Mountain, Nevada. In order to develop scaling relationships to accurately model the long-term stability of the repository, a series of parametric studies has been performed to determine the factors that strongly influence the in situ strength of the rock. This report addresses the effect of strain rate and heterogeneity on fully saturated tuff specimens from the potential repository horizon at Yucca Mountain.

\section{EXPERIMENTAL PROCEDURE}

A series of constant strain rate, uniaxial compression experiments was performed on cylinders of the Topopah Spring Member welded tuff. Each specimen was a ground right circular cylinder $50.8 \mathrm{~mm}$ in diameter and $101.6 \mathrm{~mm}$ in length. All of the specimens were cored from a block recovered from an outcrop on Busted Butte near Yucca Mountain. The specimens were tested fully water saturated. The specimens designated for testing at strain rates of $10^{-9} \mathrm{~s}^{-1}$ were characterized more thoroughly prior to testing. For each of these specimens, the porosity and bulk density were determined and a single computerized tomography (CT) scan was performed parallel to the core axis. In addition, compressional and shear wave velocities were measured parallel to the core axis. From these data, the dynamic Young's modulus and Poisson's ratio were calculated and the seismic anisotropy of the samplc was determined.

Each specimen was loaded to failure in uniaxial compression in a servo-hydraulic test frame. The strain rates were varied from $10^{-9} \mathrm{~s}^{-1}$ to $10^{-3} \mathrm{~s}^{-1}$. Each specimen was instrumented to monitor deformation during loading with LVDTs. Two LVDTs were mounted parallel to the core axis. The support rings for the LVDT barrels and the cores were separated by $50.8 \mathrm{~mm}$, and each ring was mounted approximately $25 \mathrm{~mm}$ from an end of the specimen. A third LVDT was mounted in a defnrmation ring developed by Holcomb and McNamee (1984) to monitor the radial displacement at the center of the 
specimen. From the displacement data, strains parallel and normal to the core axis were computed. The load on the specimen was measured with a standard load cell. All of the instrumentation was calibrated against standards traceable to NIST; the accuracy of the reported values is better than $\pm 2 \%$.

\section{EXPERIMENTAL RESULTS}

The results of the constant strain rate experiments on the Topopah Spring Member tuff are shown in Figure 1. At strain rates between $10^{-9} \mathrm{~s}^{-1}$ and $10^{-5} \mathrm{~s}^{-1}$, the strengths decrease with decreasing strain rate. However, the data at $10^{-3} \mathrm{~s}^{-1}$ shows a reduced strength compared to the specimens measured at a strain rate of $10^{-5} \mathrm{~s}^{-1}$.

Strength data collected at each strain rate show large scatter. The most likely explanation for these observations is heterogeneity within the specimen. The strength data at strain rates between $10^{-7}$ and $10^{-3} \mathrm{~s}^{-1}$ were collected by Price et al. (1987). In order to analyze the variations in strength observed in the previous experiments, a more thorough initial characterization of each specimen tested at $10^{-9} \mathrm{~s}^{-1}$ was carried out. For these specimens, CT scans were taken and acoustic wave velocities were measured prior to testing. Table 1 gives a detailed summary of the data collected at $10^{-9} \mathrm{~s}^{-1}$. The strength and static and dynamic elastic moduli are presented for the six specimens tested. Compressional and shear wave velocities are presented for both oven dry and saturated conditions. Two orthogonally polarized shear waves were measured with the propagation direction parallel to the core axis Assuming isotropy, these data were used to compute the dry and saturated dynamic elastic moduli.

The strengths of the rocks tested at $10^{-9} \mathrm{~s}^{-1}$ varied from 45.3 to $108.5 \mathrm{MPa}$. The scatter in these data is large. However, if the distribution of pores is examined, it is apparent that specimens with the largest vapor-phase altered and lithophysal zones, which constitute the greatest proportion of porosity in the tuff, show the lowest strengths. 
(Note: Lithophysae are gas-formed voids created soon after emplacement of the ash-flow tuff. Vapor-phase-altered zones are regions of tuff matrix altered by gases in the early stages of tuff emplacement.) The CT scans taken on specimens BB-10AE-24Z-SNL and BB-10AE-49W-SNL are shown in Plates 1 and 2. The white and lighter gray regions in the photographs represent less dense material. Higher density corresponds to darker shades of gray. Specimen BB-10AE-24Z-SNL was the strongest test in the series; specimen BB-10AE-49W-SNL was the weakest. In general, the compressional and shear wave velocities are appreciably lower in specimen BB-10AE-49W-SNL than in BB10AE-24Z-SNL. The dynamic and static moduli for specimen BB-10AE-49W were the lowest of all specimens tested at a strain rate of $10^{-9} \mathrm{~s}^{-1}$. The reason for the low values in strength and moduli becomes clear upon examination of the photographs. The central portion of specimen BB-10AE-49W-SNL is dominated by a large lithophysal and vaporphase altered zone. In fact, almost a quarter of the CT scan represents void space and low porosity material. In contrast, the $C_{1}$ scan for specimen BB-10AE-24Z-SNL shows a more uniform distribution of pores with one large low density zone in the lower left hand corner.

There is a correlation between the volume and nature of the pore spaces and the strength and moduli of the tuff. Although the porosities of the six specimens are approximately the same (between 9 and 12\%), it is the size and distribution of porous areas, as shown in the CT scans, that strongly affects the strength and elastic properties. An examination of the other four CT scans on specimens that exhibited strengths between 81 and $97 \mathrm{MPa}$ showed a more or less uniform distribution of pores.

Stress-strain data from experiments BB-10AE-24Z-SNL and BB-10AE-49W-SNL are shown in Figures 2 and 3. Young's modulus is computed from the slope of the stress versus axial strain curve between 10 and $50 \%$ of the ultimate strength. Poisson's ratio is computed from the slope of the radial strain as a function of axial strain over the same stress interval. These stress-strain curves showed an interesting feature, while there was 
nothing anomalous in the observed axial strain as a function of stress, little radial strain was observed up to the onset of failure; then, it increased precipitously. This suggests that dilatancy, commonly associated with failure in brittle rocks, is not gradual in tuff at this strain rate and scale. All the dilatant behavior is directly associated with failure.

For the $10^{-9} \mathrm{~s}^{-1}$ experiments Poisson's ratio is extremely low. The dynamic Poisson's ratio is characteristically near 0.2 , whereas the static Poisson's ratios invariably were less than 0.1 . Specimens tested at strain rates between $10^{-3} \mathrm{~s}^{-1}$ and $10^{-7} \mathrm{~s}^{-1}$ had a Poisson's ratio near 0.2; however, several specimens did show lower Poisson's ratios.

\section{DISCUSSION}

The decrease in strength with decreasing strain rate can be explained in terms of moisture assisted crack growth. Charles (1959) observed nearly a factor of two decrease in strength between granite samples tested in dry nitrogen and in saturated steam. Martin (1972), Martin and Durham (1975), and Wiederhom $(1968,1969)$ have shown that timedependent crack growth can occur in the presence of water. The time-dependent cracking is attributed to stress corrosion, a thermally activated process. The velocity of crack propagation in silicates for a wide variety of loading geometries is dependent on the applied stress (stress intensity factor), the partial pressure of water at the crack tip, and the temperature. Several models have been proposed to correlate the observed time-dependent behavior in rocks with stress corrosion cracking. A constant strain rate experiment can be idealized as a series of incremental loadings to successively higher stresses where the duration of the intervals increases with decreasing strain rate. At constant load, a crack will propagate in a time dependent manner. The longer the time at a given stress level, the more the crack will grow prior to the next increment of stress. Assuming that most rocks fail when cracks reach a critical length, the strength of a rock will decrease with decreasing strain rate. 
The decrease in strength with decreasing strain rate (shown in Figure 1) is approximately $28 \%$ decrease per thousand fold decrease in strain rate between $10^{-5}$ to $10^{-9} \mathrm{~s}^{-1}$. The effect is well documented. In addition to these data, Brace and Martin (1968) observed an $11 \%$ decrease in strength per thousand fold decrease in strain rate over the range of $10^{-7}$ to $10^{-4} \mathrm{~s}^{-1}$ for water saturated Westerly granite. Olson and Jones (1980) noted a similar strain rate dependence in tuff.

Costin (1983) proposed a lower limit to the decrease in strength with decreasing strain rate. His model is based on linear fracture mechanics and stress corrosion cracking. He suggested that at low strain rates, stress corrosion completely relaxes the tensile stress at the crack tip and arrests crack growth. He calculated a critical strain rate of $10^{-9} \mathrm{~s}^{-1}$ for Westerly granite; no data exist to verify this prediction. The data collected on tuff does not extend to sufficiently low strain rates to test the Costin hypothesis. Although relatively impractical, it would be of interest to extend the measurements that have been conducted to lower strain rates and determine whether the decrease in strength with decreasing strain rate indeed has a lower limit.

The observed decrease in strength at $10^{-3} \mathrm{~s}^{-1}$ however, is inconsistent with a single mechanism model based on stress corrosion. This behavior is most likely related to the fully saturated test conditions. An experiment at $10^{-3} \mathrm{~s}^{-1}$ only lasts several seconds. This loading rate is too great to allow diffusion of the pore water prior to failure, and results in a buildup in pore pressure. The augmented pore pressure causes hydrofracturing (crack development due to excess pore pressure) and reduced strength.

Price and Bauer (1985) reported that Young's modulus and fracture strength are related to functional porosity. Functional porosity is defined as the measured porosity plus the volume fraction of montmorillonite within the specimen. Strength and modulus decreased with increasing functional porosity. The relationship between strength and porosity is consistent with damage mechanics models developed by Ashby and Sammis (1991). With increasing initial damage, in this case vapor-phase altered and lithophysal 
zones, the strength decreases. The damage is characterized in terms of the length and density of cracks within the specimen. For the tuff specimens studied in detail, those with a uniform distribution of small lithophysal and vapor-phase altered zones show the highest strengths.

The effect can be qualitatively observed in Plates 1 and 2. Specimen BB-10AE24Z-SNL was the strongest specimen measured at a strain rate of $10^{-9} \mathrm{~s}^{-1}$. Conversely, specimen BB-10AE-49W-SNL had the lowest strength in the suite of measurements conducted at the lowest strain rate. By examining the two CT scans, it is readily apparent that specimen BB-10AE-49W-SNL was characterized by a large low density zone in the center of the specimen. Consequently, it is reasonable to expect that the strength of this sample would be appreciably lower than that of a specimen with a smaller average pore dimension and a more uniform distribution.

The relationship between static and dynamic elastic moduli is also dependent on the nature of the porosity of the rocks. Compressional and shear wave velocities are sensitive to pore (crack) length, aspect ratio, and pore (crack) density. Models have been developed by others to quantify the influence of cracks and inclusion of various aspect ratios on the elastic properties of rocks. O'Connell and Budiansky (1974) developed a self-consistent theory that showed that the elastic moduli of solids containing thin cracks depend on the crack density and crack length. For a given crack density, as the crack length increases, the velocity and associated elastic constants decrease. Other studies have shown that the presence of spherical and elliptical inclusions influence the elastic constants of the solid (Kuster and Toksöz, 1974; Berryman, 1980). These models show that as the concentration of inclusions increase, the elastic constants decrease. Based on these models, it is reasonable to expect that if the pore distribution is fairly uniform, as the length of the cracks increase, the compressional and shear wave velocities will decrease. This has been observed in the six specimens studied in detail. For example, the 
specimen with the largest pore dimensions (BB-10AE-49W-SNL) displayed significantly lower seismic wave velocities and dynamic elastic constants.

If we are to consider the effect of scale on tuff and need to predict the in situ performance of the potential repository over long periods, more information will be required, not only on the lithology of the rocks, but also on the relation between the nature of the porosity and mechanical behavior. This study is the first step in such an analysis.

\section{REFERENCES}

Ashby, M. and Sammis, C., "The Damage Mechanics of Brittle Solids in Compression", Pure and Applied Geophysics, 133, 489-521, 1990.

Atkinson, B.K., "Subcritical Crack Growth in Geological Material", Journal of Geophysical Research, v. 89, p. 4077-4114, 1984.

Brace, W.F. and Martin, R.J., III, "A Test of the Law of Effective Stress for Low Porosity Crystalline Rocks", Int. J. Rock Mech. Min. Sci., 5, 1968.

Berryman, J. G., "Long-wavelength Propagation in Composite Elastic Media II. Ellipsoidal Inclusions", Journal of the Acoustical Society of America, v. 68, (6),p. 1820-1831, 1980.

Charles, R.J., "The Strength of Silicate Glasses and Some Crystalline Oxides, in Averbach", B. L., et al., eds., Fracture: New York, John Wiley, p. 225-249, 1959.

Costin, L.S., "A Microcrack Model for the Deformation and Failure of Brittle Rocks", $J$. Geophys. Res 88 (11), p. 9485-9492, 1983.

Heuze, F., "Scale Effects in the Determination of Rock Mass Strength and Deformability", Rock Mech., 12, 167-192, 1980. 
Holcomb, D.J., and Mcnamee, M.J., "Displacement Gage for the Rock Mechanics Laboratory", SAND 84-0651, Sandia National Laboratories, Albuquerque, New Mexico, 1984.

Kuster, G.T., and Toksöz, M., N., "Velocity and Attenuation of Seismic Waves in Twophase media: Part I. Theoretical Formulations", Society of Exploration Geophysicists, 39, 587-606, 1974.

Martin, R.J., III, "Time-Dependent Crack Growth in Quartz and Its Application to the Creep of Rocks", J. Geophys. Res., 77, (8) 1406, 1972.

Martin, R.J., III and Durham, W. I., "Mechanisms of Crack Growth in Quartz", J. Geophys. Res., 80, 4837, 1975.

O'Connell, R., and Budiansky, B., "Seismic Velocities in Dry and Saturated Cracked Solids", J. Geophys. Res., 79, 5412-5426, 1974.

Olsson, W.A. and Jones, A.K., Rock Mechanics Properties of Volcanic Tuffs from the Nevada Test Site, Sandia national Laboratories Report, SAND80-1453, 1980.

Price, R.H., and Bauer, S.J., "Analysis of the Elastic and Strength Properties of Yucca Mountain tuff, Nevada", Proceedings of the 26th US Symposium on Rock Mechanics, Rapid City, SD June 26-28, 1985.

Price, R.H., "Effects of Sample Size on the Mechanical Behavior of Topopah Spring Tuff", SAND85-0709, Sandia National Laboratories, 1986.

Price, R.H., J.R. Connolly, K. Keil, Petrologic and Mechanical Properties of Outcrop Samples of the Welded, Devitrified Topopah Spring Member of the Paintbrush Tuff, Sand86-1131, Sandia National Laboratories, 1987.

Scholz, C.H., "Static Fatigue of Quartz", J. Geophys. Res. 77 (11), p. 2401, 1972.

Wiederhorn, S.M., "Moisture Assisted Crack Growth in Ceramics": International Journal of Fracture Mechanics, v. 4, p. 171-177, 1968.

Wiederhorn, S.M., "Fracture of Ceramics", in Mechanical and Thermal Properties of Ceramics: National Bureau of Standards Publication, 303, p. 217-241, 1969. 


\section{Figure Captions:}

Figure 1: The fracture strength of water saturated specimens of Topopah Spring Member tuff tested in uniaxial compression are plotted as a function of strain rate.

Figure 2a: Stress is plotted as a function of axial strain for a specimen of Topopah Spring Member tuff (BB-10AE-24Z-SNL) tested in uniaxial compression at a strain rate of $10^{-9} \mathrm{~s}^{-1}$.

Figure 2b: Radial strain is plotted as a function of axial strain for a saturated specimen of Topopah Spring Member tuff (BB-10AE-24Z-SNL) tested at a strain rate of $10^{-9} \mathrm{~s}^{-1}$ under ambient conditions.

Figure 3a: Stress is plotted as a function of axial strain for a specimen of Topopah Spring Member tuff (BB-10AE-49W-SNL) tested in uniaxial compression at a strain rate of $10^{-9} \mathrm{~s}^{-1}$.

Figure 3b: Radial strain is plotted as a function of axial strain for a saturated specimen of Topopah Spring Member tuff (BB-10AE-49W-SNL) tested at a strain rate of $10^{-9} \mathrm{~s}^{-1}$ under ambient conditions.

Plate 1: A CT scan of specimen BB-10AE-24Z-SNL of theTopopah Spring Member tuff.

Plate 2: A CT scan of specimen BB-10AE-49W-SNL of theTopopah Spring Member tuff. 


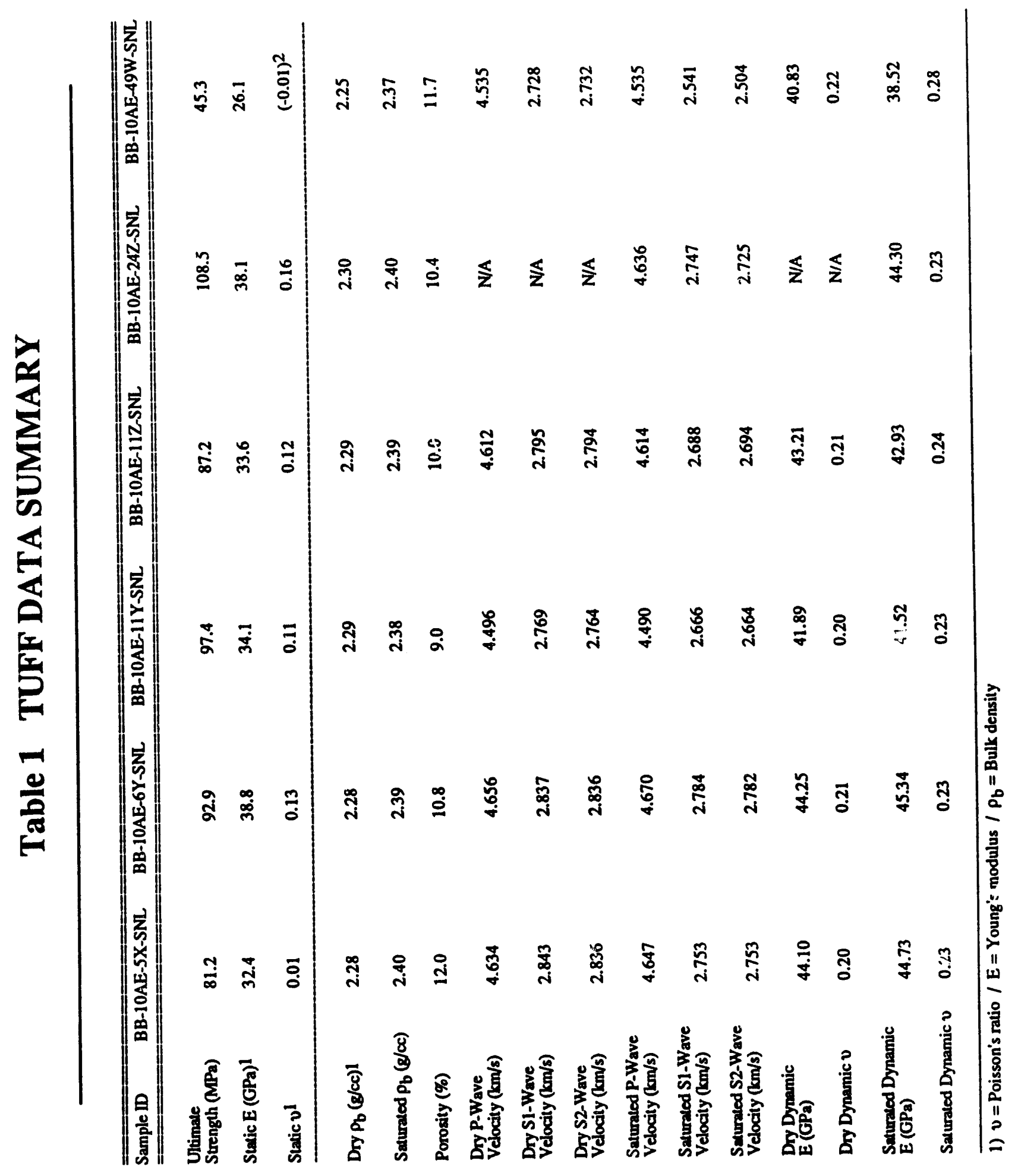


Topopah Spring Member Tuff

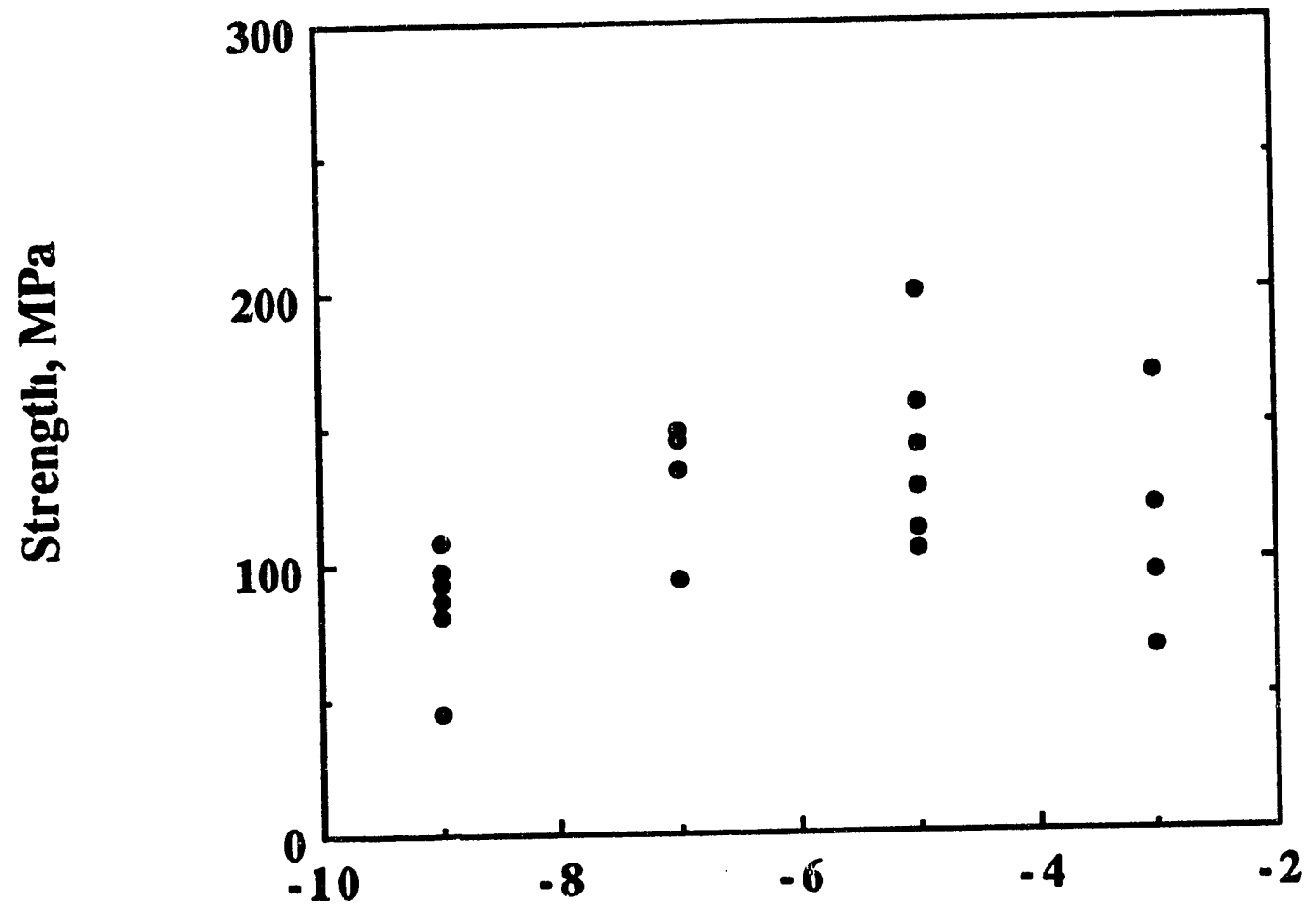

Log Strain Rate, /sec

Figure 1 

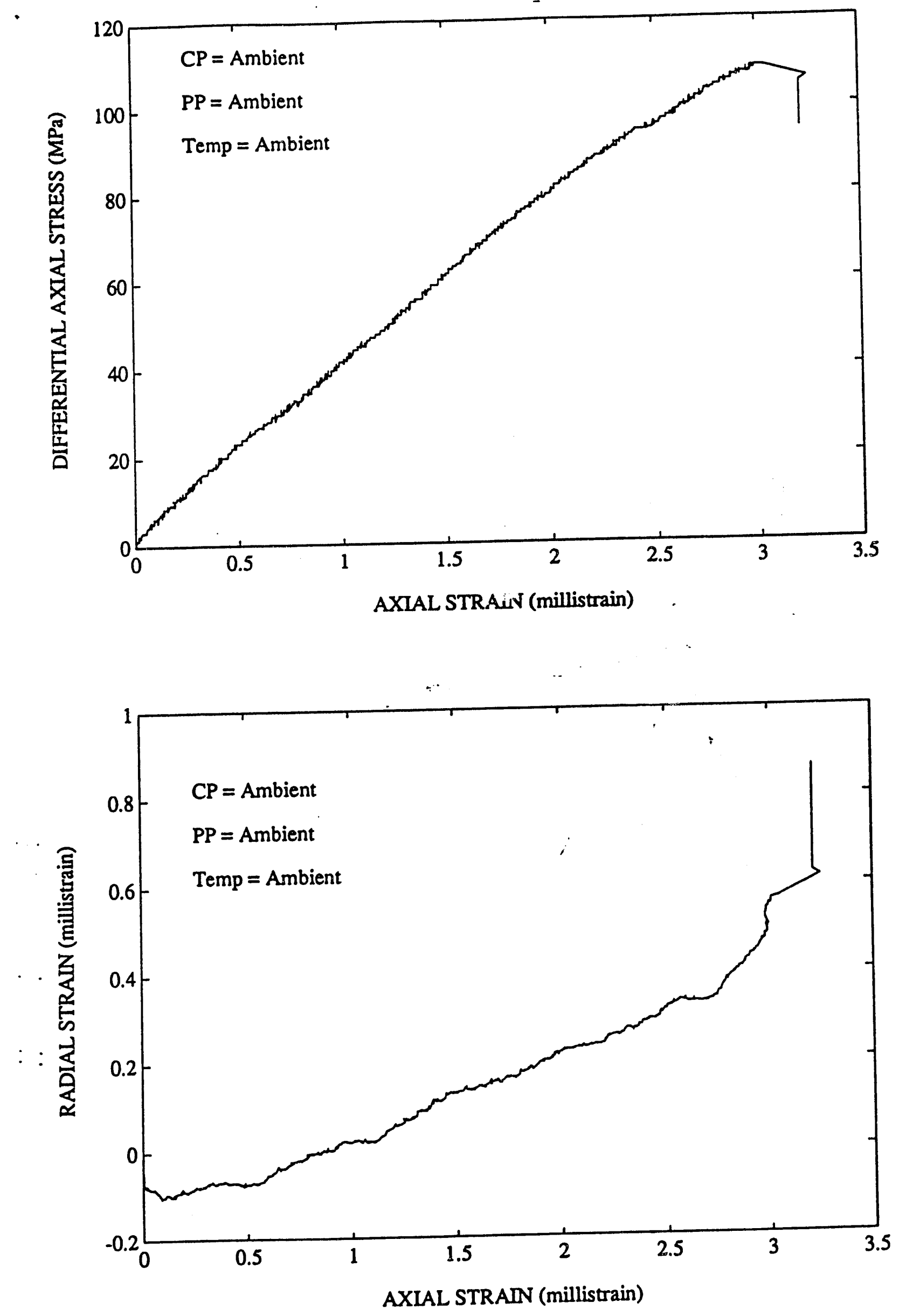

Figures $2 a$ \&े $b$ 

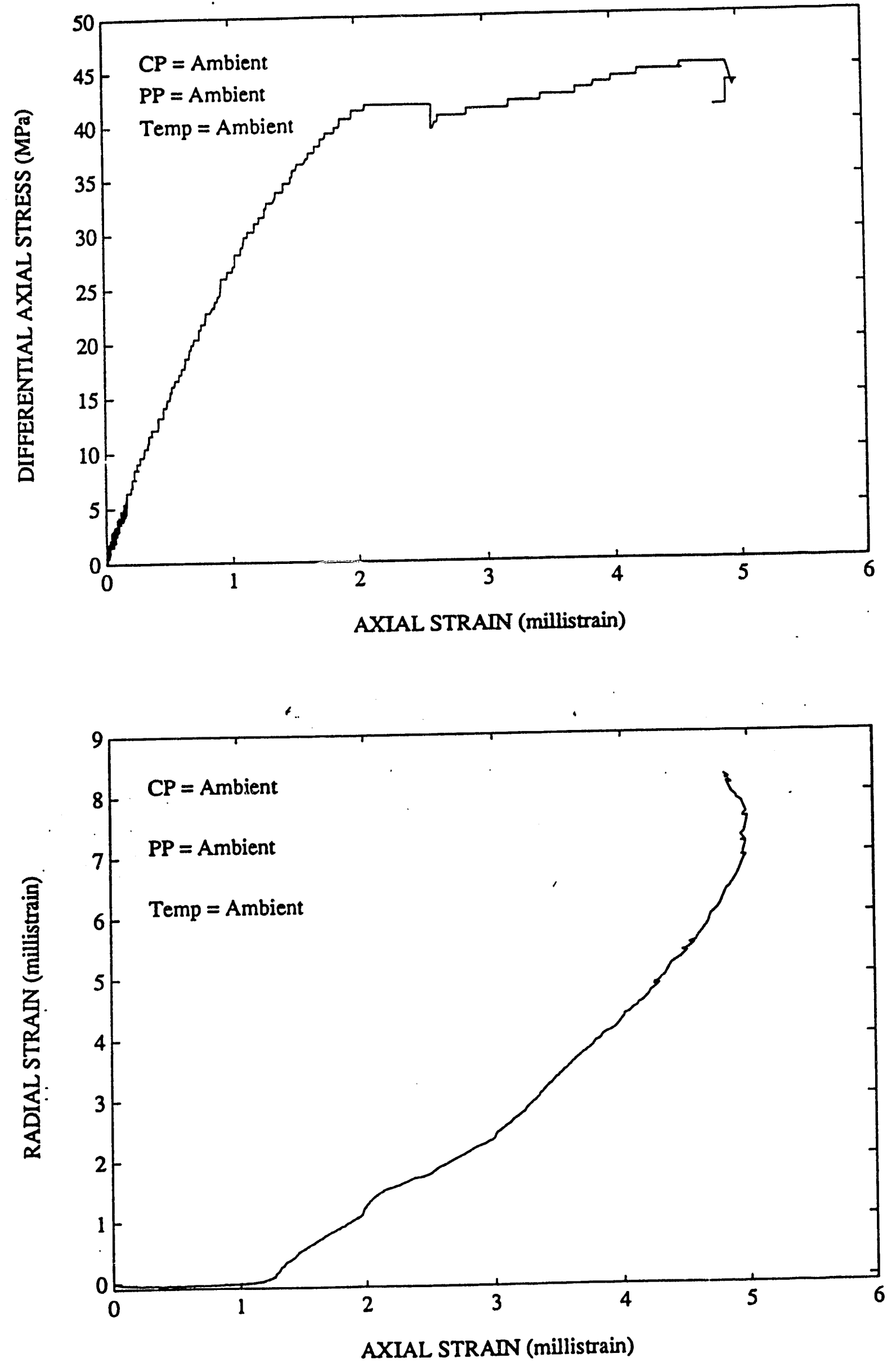

Figured $3 a, b$ 


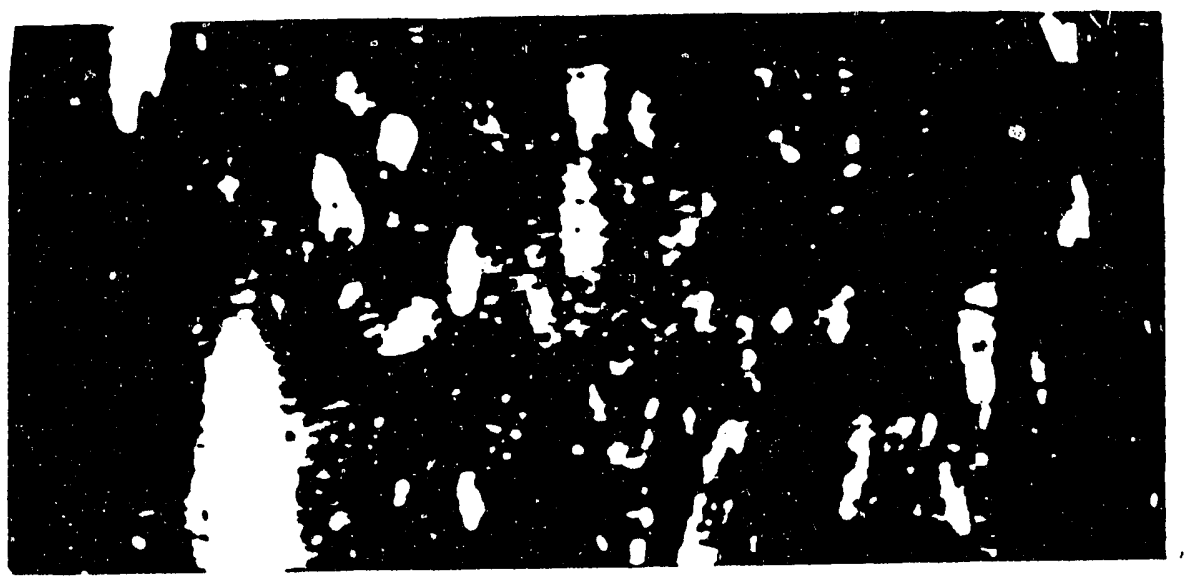

Plate I 


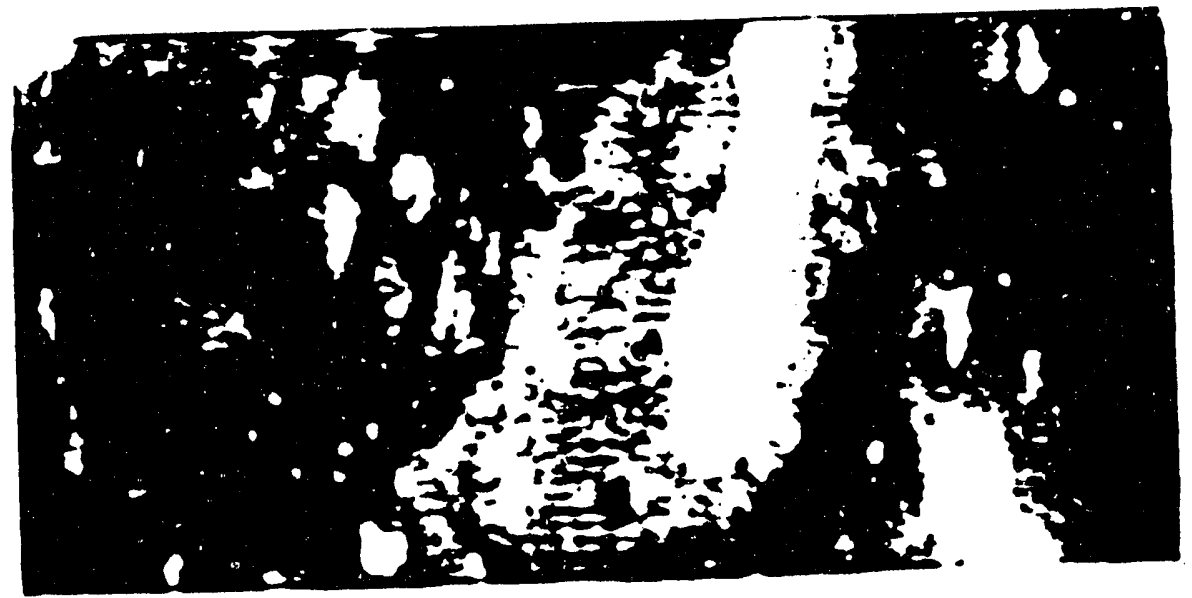

\section{DISCLAIMER}

This report was prepared as an account of work sponsored by an agency of the United States Government. Neither the United States Government nor any agency thereof, nor any of their employees, makes any warranty, express or implied, or assumes any legal liability or responsibility for the accuracy, completeness, or usefulness of any information, apparatus, product, or process disclosed, or represents that its use would not infringe privately owned rights. Reference herein to any specific commercial product, process, or service by trade name, trademark, manufacturer, or otherwise does not necessarily constitute or imply its endorsement, recommendation, or favoring by the United States Government or any agency thereof. The views and opinions of authors expressed herein do not necessarily state or reflect those of the United States Government or any agency thereof. 

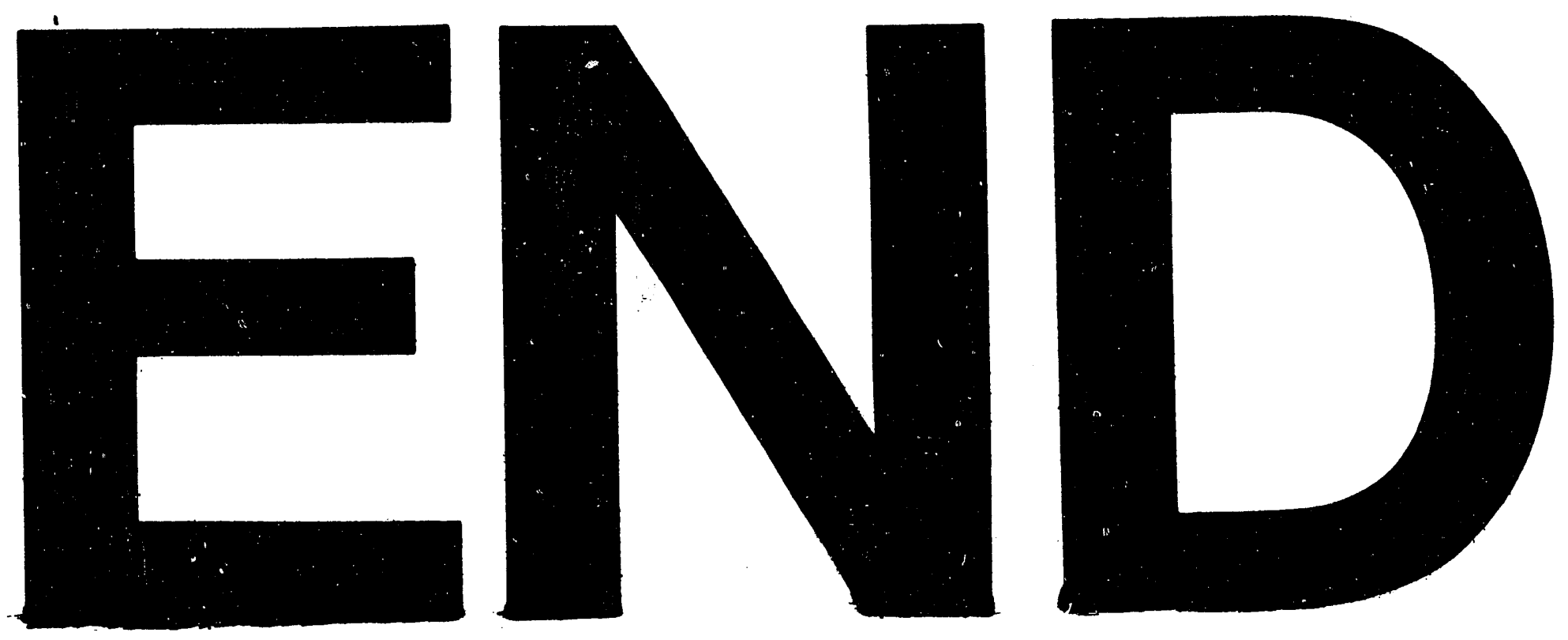

6

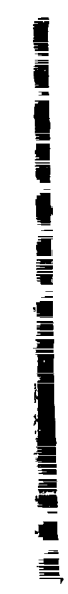
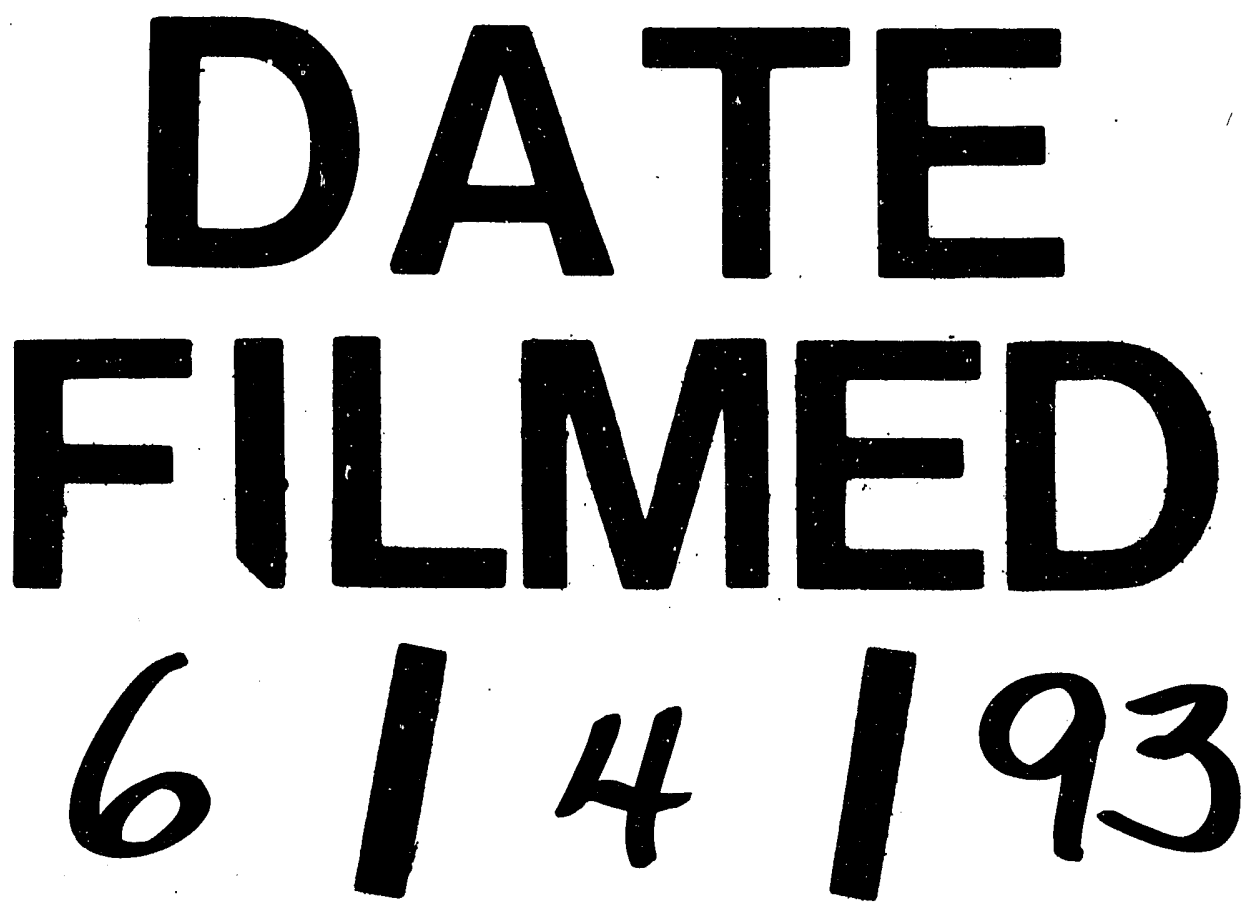


$$
\text { r }
$$<smiles>C=C</smiles><smiles>[I-]c1ccccc1</smiles>
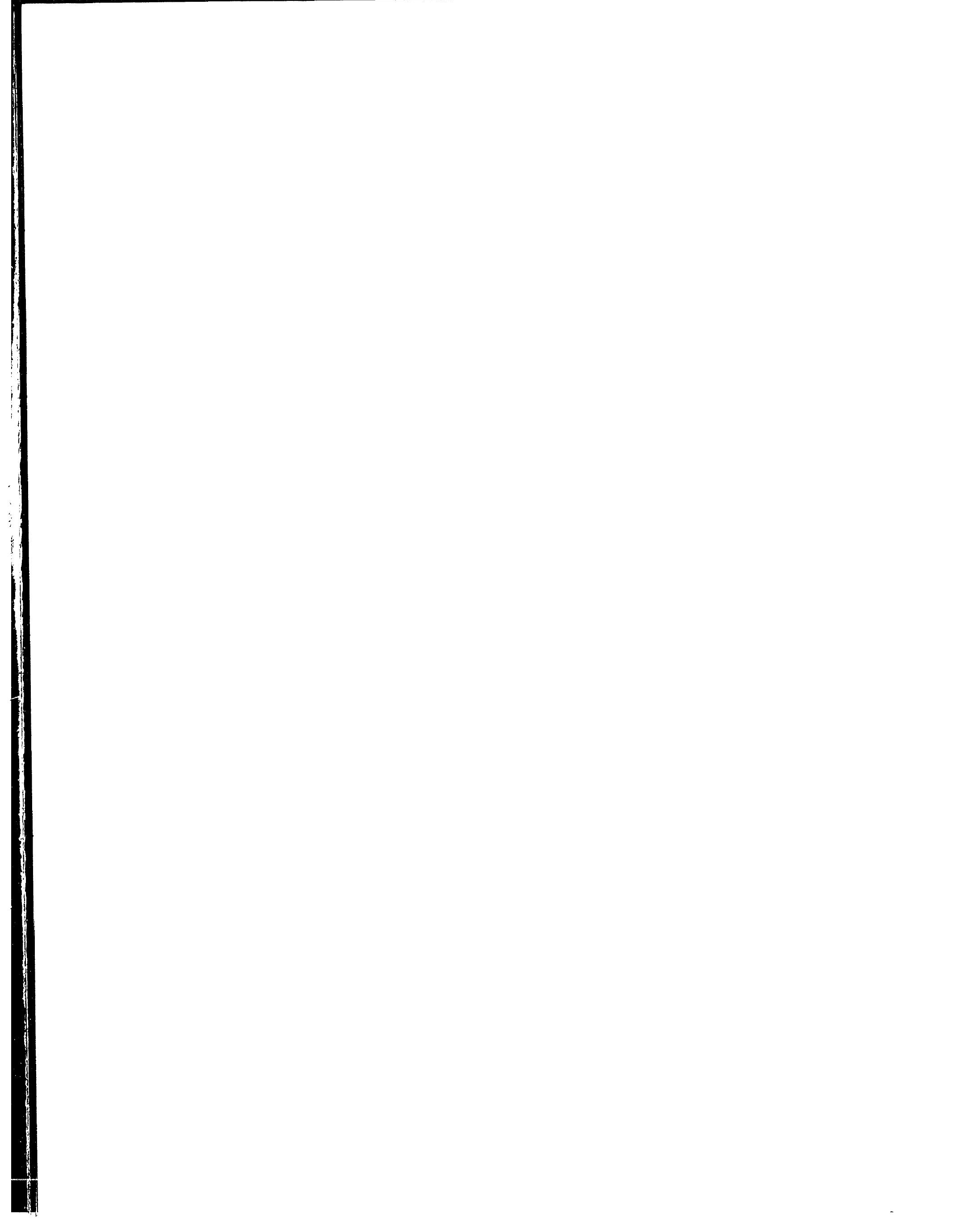

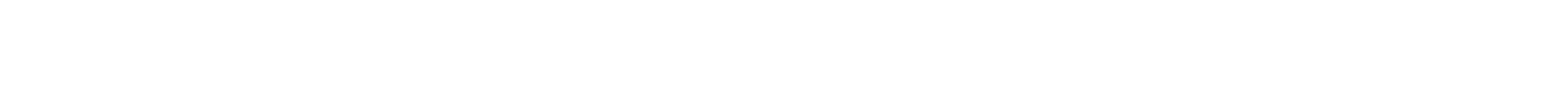
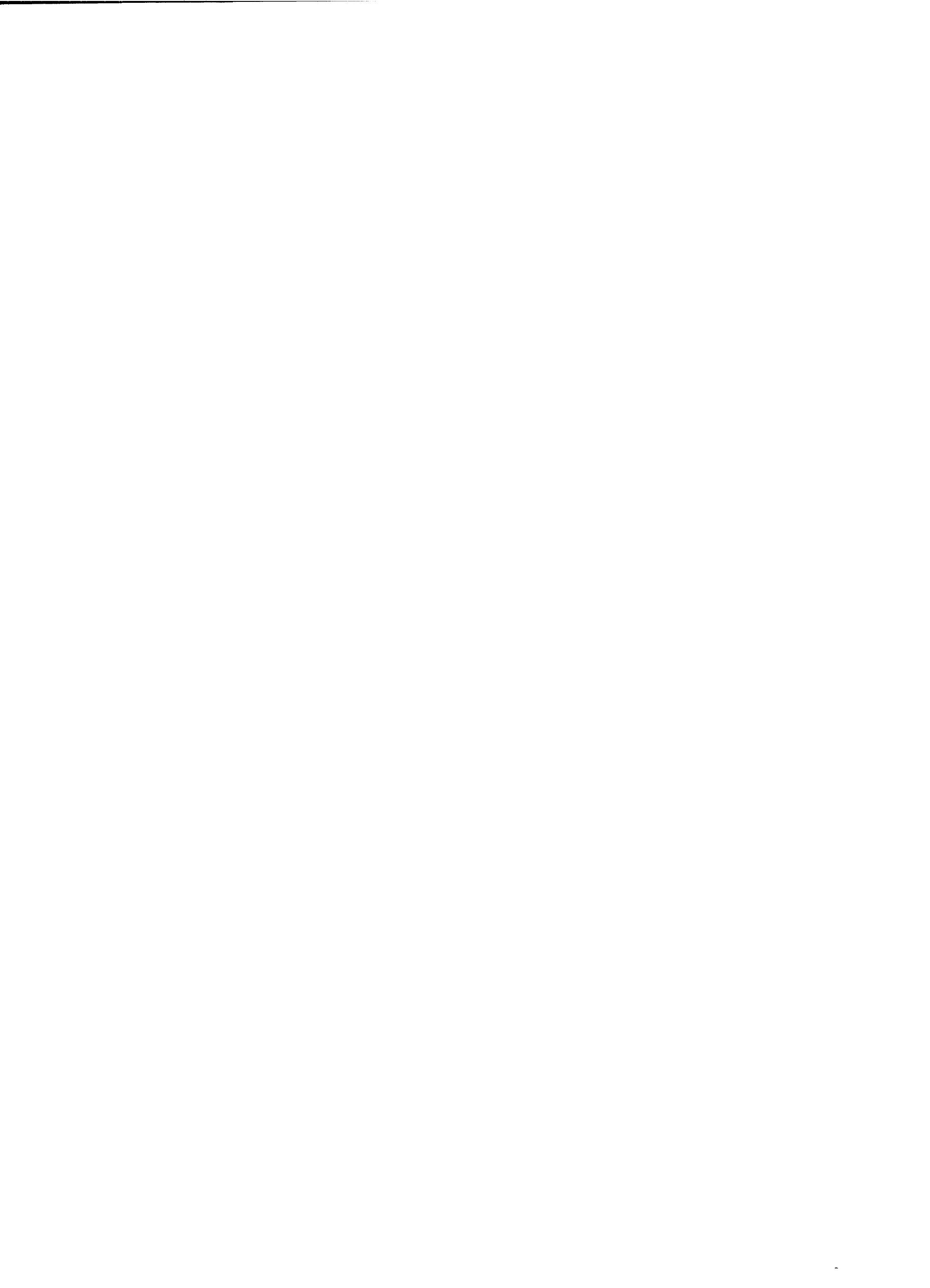